\title{
Analysis of University Students' Argumentation Writing
}

\author{
Yusak Hudiyono $^{1}$, Ahmad Ridhani ${ }^{2}$ \\ ${ }^{1,2}$ Faculty of Teacher Training and Education, Mulawarman University, Indonesia \\ yusak.hudiyono@fkip.unmul.ac.id,ridhaniahmad16@gmail.com
}

\begin{abstract}
This paper finds the argumentation patterns of Mulawarman University's students in writing that include (a) patterns of consideration in writing arguments (b) dominant patterns in writing arguments and (c) the types of mistakes made in writing arguments. The research used discourse analysis of argumentation of content analysis model. The result of the research shows that the argumentation pattern used by Mulawarman University students is using authority consideration as much as $\mathbf{3 . 8 \%}$, consideration of empirical data as much as $15.4 \%$, rational consideration $55,8 \%$, and use reader's emotional consideration as much as $25 \%$. Thus, dominance used by students in writing arguments is a rational consideration. The type of mistake made by the student is in the use of the spelling of writing in as a greeting and as a front word. Another error is the formation of the word that is as a particle and as a connector. From the research result suggested that there is training of argumentation writing which use various variation of consideration.
\end{abstract}

Keywords-writing pattern, argumentation discourse, university mulawarman

\section{INTRODUCTION}

Disclosure of thoughts in written discourse includes, among other things, the arguments presented. The quality of the argument depends on the defended or verified proposition accompanied by the evidence used to support the proposition. The argument according to [2] is part of the argumentative process used by the person who puts forward the argument. The people who make the argument do reasoning from acceptable standpoints to the stands that are opposed by the public. In other words, one's argument is reflected in the ability to associate propositions or establishments with evidence to convince others appropriately and correctly. Another argument says that argumentation is the process of making arguments aimed at justifying beliefs, attitudes, and values so as to influence others [12]. Argumentation is one form of a persuasive process. Its role is to convince others through clear reasons and strong evidence that a certain value or point of view should be taken. The power of argumentation depends on the precision of the structure of the argument builder elements. Broadly speaking, the structure of the argument can be distinguished over simple arguments and complex arguments [3].

Based on the background of the problem can be formulated how is the ability to write the argumentation discourse of students Mulawarman University (UNMUL)? The general problem formulation is detailed in the following specific research formula. (a) What is the writing pattern of Mulawarman University student's argumentation discourse? (b) What is the dominant pattern in student argumentation writing in Mulawarman University? And (c) How are the forms of student argumentation error in Mulawarman University? (d) What strategies are used in correcting student argument writing errors in Mulawarman University?

Based on the background of the problem and the formulation of the problems that have been raised, the general objective in this research is to analyze the ability to write the discourse of argumentation of Mulawarman University students. The general objectives of the study are detailed in the specific objectives of the following study. (a) Analyzing the pattern of writing discourse of student argument Mulawarman University. (b) Analyzing the dominant pattern in writing student arguments in Mulawarman University. (c) Analyzing forms of student argument writing errors in Mulawarman University. (d) Describe the strategies used in correcting student argument writing errors in Mulawarman University.

The pattern of developing the argument's discourse is the rhetorical tool in the argument text to convince the reader of the truth or untruth of an argument by relying on various types of appeal, namely (1) appeals to the writer's own credibility (authority); (2) appeals to empirical data; (3) appeals to reason (logical appeals); and (4) spontaneous to the reader's emotions, values, or attitudes (pathetic or affective appeals)

\section{THEORETICAL REVIEWS}

The argumentation discourse contains an offer of evidence to support a proposition, as [10]. Arguments are conveyed to affirm the true value of a proposition. It was also suggested by $[6,7]$ that the argumentation contains a proposition to prove a truth or error. The writing of the argument is written to influence and change an idea by offering evidence of the object being argued. \#

The main signifier of the argumentation discourse is the logical relationship between the two. There are three points to consider in the preparation of the argumentation writing discourse, namely (1) the source of the information giver, (2) the message conveyed, and (3) the recipient of the message. The source of the informer is related to the credibility of the sender and the feelings generated by the source. To convey the rules in the school, the principal is more competent than if the homeroom who delivered it. 


\section{RESEARCH METHODOLOGY}

The exposition of propositions on a discourse is determined by its purpose, because one can know that basically a writing is made to achieve a certain goal, perform certain functions, and have a certain core [1]. The interrelationship between form and function, exposure and purpose, arises in various compositional processes. Modifiable forms and functions in the composition process may occur, but are determined by the main intentions of the exposure.

The author seeks to convince the reader through the validity of the argument by using evidence effectively. As a writer, one must also use evidence to influence the reader to accept the proposition conveyed. The use of evidence can be done for example, a person uses a quote from a poem or from a literary critic on a literary essay or a person using data from an experiment in the laboratory as a report material. One important element in an argument is the drawing of a conclusion. Mehra and Burhan suggest that drawing a conclusion is the process of obtaining a proposition drawn from one or more propositions [9]. Conclusion drawing is done over more than one proposition and if stated in the language is called an argument. Furthermore, it is also explained that drawing conclusions is generally done deductively and inductively. On deductive withdrawal, conclusions cannot be more general in character than their premises; whereas inductively, conclusions must be more general than their premises. Drawing deductive conclusions may be done directly or indirectly. Direct drawing of conclusions is a deductive process whose conclusions are drawn from a single premise, whereas indirect conclusions are conclusions drawn from two or more premises. The conclusions drawn from the two propositions placed at once called syllogism. Discourse of argument is a discourse that consists of exposure reasons and thesis opinion to build a conclusion. The discourse of argumentation is written with the intent to give reasons, to reinforce or reject an opinion, opinion, or idea. Argumentation is a discourse that proves the truth or the unfairness of a statement [10]. The author uses various strategies or tools of rhetoric in the text of the argument to convince the reader of the truth or untruth of an argument. Arguments rely on various types of appeal, i.e. appeals or considerations [10]. The authors of argumentation discourse use different types of appeal in developing the argumentation discourse pattern. Types of appeal that are commonly used by the authors of argumentation discourse described below. First, the appeals to the writer's own credibility (authority) refers to the credibility or authority of the author by showing himself to master a lot of issues by still appreciating the reader's views. Second, appeals to empirical data refers to the consideration of empirical data by presenting primary or secondary data to substantiate the argument. Third, appeals to reason (logical appeal) refers to reason or logical reasoning, i.e. reasoning appropriately when submitting opinions with convincing evidence. Fourth, spontaneity to the reader's emotions, values, or attitudes (pathetic or affective appeals) refers to values, emotions, and attitudes by selecting examples and raising issues that are expected to undermine the reader's feelings by using language rich in meaning connotation [11-13].
This study aims to analyze the ability to analyze the discourse of argumentation of Mulawarman University students. Based on the purpose of the research, the type of research used is the type of qualitative research using descriptive interpretation approach. By analyzing and interpreting the ability to write the discourse of argumentation of Mulawarman University students. The stages of this study include stage (1) the making of research instruments, (2) data collection, and (3) data validation. Making the instrument of research done in the first month of this research conducted (February 2016). The making of research instruments refers to the creation of the task of writing argumentation discourse by using drawings and guides of argumentation discourse. \#

Data collection is done through the assignment given to the students so that they write the argumentation discourse Triangulation method is done by using drawings and guidance of writing argumentation discourse. Data analysis in this study used the communication content analysis model adapted from [8]. Data analyzed by interactive model include steps, namely (1) data formation, (2) data reduction, (3) data exposure, and (4) conclusion drawing and verification. The four steps are described below. The analysis of the corpus is done to sort the elements of research variables so that they can be processed and presented in accordance with the argument elements, argument types, and argument structures in the discourse of writing high school students' argumentation. Based on the principle of analytic induction, then procedurally, the analysis of this data corpus includes the identification of indicators of each variable (sub variable), indicator elements, and justification pattern of each variable (sub variable). Furthermore, the results of corpus data analysis presented in the form of description of the research results.

The inference of the data corpus is carried out inductively through the discovery of the meaning of its regularity, the patterns, the explanations it can give, the configurations corresponding to the argument element, the argument type, and the structure of the argument in the discourse of the argumentation of the high school students. Data corpus verification refers to the argument element, argument type, and argument structure in the high school students' argument written argument written during the analysis. Review of various inference guides with sufficient interpretation and evidence-gathering records to support the truth. To make it easier to analyze research data formulated research indicators.

\section{RESUlTS AND DISCUSSION}

\section{A. Mulawarman University Student's Argument Writing Pattern}

The Mulawarman University's writing patterns use four patterns.

1. The appeals to the writer's own credibility (authority), the appeals to the writer's own credibility (authority), refers to the credibility or authority of the author by showing himself mastering a matter by still appreciating the reader's views. The pattern of credibility of the author into consideration on the writings of arguments that can be seen from the object 
of writing. Writers who work as police (students of Mulawarman University cooperation with East Kalimantan Police) write a topic related to matters pertaining to the police. Seen from the titles of their writing. This is evident from the writings of those who talked interesting experiences about the task at the police. The discourse of the argument in the article entitled Opumpasi Tumpas Matoa 2011 becomes one of the argumentation writings that have cirri consideration of author's credibility. In the discourse is disclosed how the lunge operations conducted by the author in the tasks in Papua, in the District Puncak Jaya. From some argumentation writings it can be concluded that the argumentation pattern uses consideration of authority. Nevertheless, there is still a pattern of argument with authority, not too much. Thus it can be concluded that the writings of students are not many who use authority as a tool of argument.

2. Pattern argumentation by using consideration of empirical data (appeals to empirical data). Notice the following discourse. 'Satu sisi harga minyak dunia akhir-akhir ini terus merangkak naik dari tahun-tahun lalu terjun bebas hingga berkisar 35\$ US" (data03). The argument used in student writing refers to the consideration of empirical data by presenting primary or secondary data to substantiate the argument. The argument presented in the above article uses the consideration of empirical data as a means of argumentation. The writing that oil prices are crawling from year to year but then plummeting around 35 \$ US. That shows the strengthening of the data by mentioning the value of the decline of 35 \$ US. The use of empirical data to convince readers by raising the rate of economic growth in Indonesia to $7 \%$.

3. Appeals to reason (logical appeal). Writing arguments that use rational logic considerations in order to convince readers to accept and agree with the content of the text can be seen in the text that uses rational logical reasoning to convince the reader through the expression that "Pertamina does not want the increase to occur as it will become a burden for the people to increase" the rational acceptability of the assertion that the fuel price hike will certainly be followed by price increases and the price increase will add to the burden. Thus, rational considerations can be used as an attempt to convince the reader. The use of arguments with rational considerations is also found in the following paragraph example. The authors express rational considerations by raising rational reasons such as the causes of floods that occur due to natural factors, human factors as contained in the following paragraph (data19). Penyebab banjir biasanya dikarenakan curah hujan yang tinggi, adanya sampah yang mengganggu aliran air, penambangan galian $C$ yang tidak mengikuti arahan amdal sehingga membuat pendangkalan. (data19). Rational argument as written in data (019) illustrates the existence of a link between the flood and the presence of waste in the watercourse. The existence of the construction of excavation $\mathrm{C}$ which does not follow the sustainability effect analysis $(A M D A L)$. The existence of siltation due to excavation of $\mathrm{C}$ and garbage that is in the flow of sewer water. The reader is directed to the logic that if the flow of water is not smooth which is in the trench over time the ditch will be full and the moat filled with water will overflow up to the road so the road will be inundated. That is what writers use to give consideration in the writing of argumentation.

4. Appeals to the reader's emotions, values, or attitudes (pathetic or affective appeals) The following pattern of argumentation using emotion, reader, appeals ) The consideration is done with the intent of the author to be able to melt the feelings of the reader The language used is rich in its connotative meaning The use of phrase triggers protests and phrases over the limit in the text above gives the impression that the emotions of the reader appear The reader will feel something is disturbing emotion with these words. Thus, the purpose of writing argumentation reaches the target because basically the writing of the argument is intended for the reader to feel something that is believed and believed to follow and justify the argument. In consideration involves the emotions of readers of the following article also extension of readers' emotions.

\section{B. The Dominant Pattern of Argumentation}

The dominant pattern in writing student arguments in Mulawarman University. The use of argumentation tools used by students in writing papers can be seen in the following list.

TABLE I. DOMINANT PERCENTAge

\begin{tabular}{|l|l|l|l|}
\hline No & Tool Argument & $\begin{array}{l}\text { Respondents } \\
\text { Percentage }\end{array}$ & Percentage \\
\hline 1 & Authority & 2 & $3.85 \%$ \\
\hline 2 & Empirical data & 8 & $15.4 \%$ \\
\hline 3 & Rational & 29 & $55.8 \%$ \\
\hline 4 & Emotional & 13 & $25 \%$ \\
\hline & Total & 52 & $100 \%$ \\
\hline
\end{tabular}

Judging from the data in table no. 1 above note that the use of consideration using authority (authority) in writing contained in 2 posts $(3.85 \%)$. This means that the writing of arguments that are not very much done by students is to use the consideration of authority (authority). It is understandable because students usually feel less have authority when discussing about a problem because they do not feel the courage to show themselves in writing. Students feel they still do not have a clear identity identity. That is why from a number of student writings most of them have not shown any argumentation by using their authority. The use of consideration of empirical data in argumentation is a way that not many students do because it required some requirements that must be completed. Students are required to prepare and write accurate data before they write. The empirical data to be written must also be obtained in a legitimate way. Obtained accurate field data. The data must also be obtained in a way that meets the scientific criteria. In addition, the data must come from legitimate and legitimate sources academically. The obtained data obtained is derived from an inaccurate and illogical way, then it becomes meaningless and cannot be used to be a force of argumentation. That is why students do not use empirical data as a consideration of their arguments. 
The use of emotional considerations in student argumentation is known as many as 13 posts (25\%). Emotional uses include those chosen by students in argumentation rather than empirical or authority data. Argumentation writing that uses the reader's emotional considerations is done by using word choice and sorting information in reaching the effect of the reader's emotional impact. The readers of argumentation are faced with a choice of words that touch their emotions. That is what is expected by the author so that the reader touched his emotions after seeing / reading the article.

The reader's emotional considerations besides word choice, are also used for sorting information. The data that is considered important is expressed in the future then followed by other less important information. The goal is to reach out to the emotions of the reader to engage emotionally after being informed by using the sequencing. The information conveyed in the initial argumentation is considered important and the subsequent information is considered less important. The order of information delivery in writing affects the reader. The reader finds the initial information as something that is understood first and then followed by other less important information. Emotionally the reader will be very familiar with the information that comes first compared to the coming next. Thus in argumentation it becomes important to place the order of information as the basis of writing to influence the reader's emotions. The pattern of consideration in writing argumentation can be summarized as follows: (1) the most dominant rational considerations, (2) considerable emotional considerations of the reader, (3) consideration of empirical data is not widely used, and (4) the least regarded pattern is the use of authority considerations. Seeing the sequence of trends can be understood as a very realistic phenomenon. Starting from the most avoided students is to use the pattern of consideration of the authority because students do not have the authority possessed by them. Students feel still in the learning stages by rationalizing their own ideas [3-5].

\section{Forms of Argumentation Writing Errors}

Forms of forms of student argument writing errors in Mulawarman University. In terms of the dominant error can be seen from the following points. (1) Improper use of spelling. The most common type of spelling mistake is the use of a preposition word joined with a word that follows it like at home written by a student at home. They cannot distinguish between in as the prefix and in the foreground. They use it incorrectly and disrupt both. It should be written separated by the following word, as in the market and the use of it as in the beginning as in the example taken.

The use of any word as particle is also written in a way combined with the word it follows if in a word however, though, andaipun. Even if the writing of a particle in writing if followed by a word like me should be written separately I too, any house, any pain. In the student's writing there is a mistake that is written should be, namely sayapun, sakitpun, and rumahpun.

Another example of spelling mistakes is capital letter writing. Post ... The Drainage ... function occurs in student writing that should be written in lowercase like drainage function. The writing is used with the wrong rule because not all foreign words use capital letters. Capitalization is used only for names, country names, and other geographic names. Many Samarinda towns are written wrongly like the city of Samarinda.

Abbreviations in scientific writing are still used inappropriately. Written word with $y g$. Likewise there is the writing of words by being $\mathrm{dg}$. In scientific writing is not allowed to abbreviate the words. Abbreviations should only be used for words that are commonly written in cassava, such as $a . n$ to write on behalf, the word gr is used to write the word gram. Such are some of the less precise spelling writing that occurs in student argumentation. Continuous writing errors will have an impact on other readers when viewing the text. The reader assumes that the writing he reads is true and then follows it so that there are continuous errors.

Incorrect capitalization of letters lies in some of their argumentation. Capital letter writing in almost everything. It is not distinguished whether to use capital or not. All letters in writing using capital. Writing errors using all capital letters are in 14 posts. The use of several incorrectly capitalized letters is in several writings.

\section{REFERENCES}

[1] Brooks, C. \& Warrant, R.P. 1949. Modern Rethoric. New York: Harcourt, Brace Company.

[2] Cummings, L. 1999. Pragmatics, A Multidisciplinary Prespective. New York: Oxford University Press Inc.

[3] Dawud. 1998. Reasoning on Indonesian Basic School Student Tutor. Unpublished dissertation. Malang: IKIP Malang.

[4] Dawud. 2008. Argument on the Popular Argumentative Writing Language. Journal of Language, Literature, and Teaching. Year 36 (1): 41-48.

[5] Dawud. 2010. Learning to Argument Write Bahasa Indonesia. Speech inaugural Professor of Language Learning Sciences at the Faculty of Letters Presented at the Senate Open Session State University of Malang, September 30, 2010. Not published. Malang: State University of Malang.

[6] D'Angelo, F.J. 1980. Process and Thought in Composition: With Handbook. Cambridge, Massachusetts: Winthrop Publishers, Inc. Holsti, O.R. 1969. Content Analysis for the Social Sciences and Humanities. Reading: Addison-Wesley.

[7] Keraf, G. 2010. Arguments and Narratives. Jakarta: Gramedia Pustaka Utama.

[8] Krippendorff, K. 1980. Content Analysis: An Introduction to its Methodology. Beverley Hills, CA. Sage.

[9] Mehra, P.S. and Burhan, J. 1988. Introduction to Traditional Logic. Bandung: Bina Cipta.

[10] Purwosunarto, Nodya. 2016. Authorship of Argumentation. http: //hestunodya.blogspot.co.id.html (online) accessed December 12, 2016. Temple, C ;

[11] Nathan, R; Burris, N .; and Temple, F. 1988. The Beginnings of Writing. Boston: Allyn and Bacon, Inc. Team Developer, 1994. Indonesian Scientific. Malang: FPBS IKIP Malang.

[12] Warnick, B. and Inch, E.S. 1994. Critical Thinking and Communication. New York: Macmillan Publishing

[13] Company. Zaimar, O.K.S and Harahap, A.B. 2009. Discourse Review. Jakarta: Intercultural Institute 